\title{
JUURNAL.RU
}

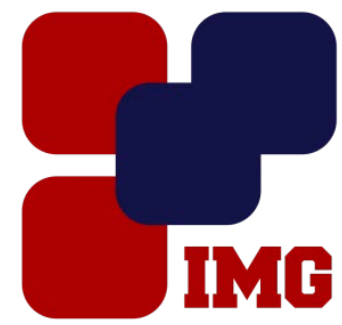
IYANOY Management GROUP

Богданова О.В., Лузина Ю.Л., Филатова Ю.Д. Донской Государственный Технический Университет Ростов-на-Дону, Россия

doi: 10.18411/lj-31-01-2017-4-12

idsp 000001:lj-31-01-2017-4-12

\section{Кинетическая архитектура - архитектура движения}

Архитектура не стоит на месте, она стремительно развивается и совершенствуется, как и технический прогресс, облегчая жизнь человеку. Современные здания не только выполняют свои функциональные задачи, но и динамически изменяются, шагая в ногу с нынешним обществом. Так, например, на сегодняшний день лидирующим направлением в архитектуре является кинетическая архитектура. Кинетизм это одна из форм трансформации, в которой создаются сложные движущиеся конструкции.

Кинетическая архитектура - это новое веяние в современной архитектуре. Её суть в том, что части здания, такие как фасад или даже этажи, могут изменять свое положение относительно друг друга, не нарушая целостность сооружения.

Отличия кинетической архитектуры от привычной:

1. Изменяющаяся форма здания

2. Динамический метод строительства

3. Возможность автономного существования

Самой первой и простой формой кинетической архитектуры является подъемный мост, используемый еще в Средневековье и даже раньше. Многие поколения архитекторов мечтали сделать архитектуру подвижной, но до XX века эксперименты проводились только в области мостостроения. Но в начале прошлого столетия возможность практического применения кинетической архитектуры стала возможной. Это обусловлено новыми достижениями в таких областях как механика, электроника и робототехника. Впервые мысль о кинетической архитектуре была выдвинута благодаря футуристическому движению. В первой трети XX века появились первые книги с планами и чертежами подвижных зданий, самой яркой из которых является книга «Архитектурные фантазии. 101 композиция» (1933 год) Якова Чернихова. А к сороковым годам начались первые практические эксперименты в этом направлении. К советским экспериментам проектирования зданий с движущимися элементами относятся такие как башня «III интернационала» архитектора Владимира Талина, или здание газеты «Ленинградская правда» Константина Мельникова. В обоих проектах были задуманы вращающиеся элементы, которые так и не воплотились в жизнь. 
На данный момент сформировано несколько типов кинетической архитектуры:

1. Функциональные строения. Примером являются мосты, имеющие подвижные пролетные конструкции, а так же конструкции с выдвижными крышами.

2. Здания-трансформеры. Строения способные менять форму не нарушая общую целостность структуры здания.

3. Отличием третьего типа заключатся в том, что движение происходит на поверхности здания.

4. Сочетание современных технологий с охраной окружающей среды.

Кинетическая архитектура зрелищна и пока необычна. Наиболее эффективным проектом такого рода признан современный многофункциональный стадион Veltins-Arena, расположенный в немецком городе Гельзенкирхен, у которого по команде отъезжает в сторону крыша. Еще одним примером кинетической архитектуры является треугольный кампус в Дании - Syddansk Universitet c «умным» фасадом. Здание имеет множество треугольных элементов в фасаде и внутренней отделке. Так, на фасаде установлено 1600 подвижных солнцезащитных панелей, в точности повторяющих форму постройки. Вмонтированные в них сенсорные датчики отслеживают уровень температуры и естественного освещения. Приборы соединены с панелями, которые меняют положение, защищая здание от перегрева внутренних помещений. Еще одним кинетическим фасадом, защищающим офисные помещения от солнечного света, является пара башен Al Bahar в Абу-Даби имеющих «отзывчивые фасады». Интересные геометрические фигуры, которыми как бы обёрнуты башни, создают необычный визуальный эффект, и в то же время надёжно защищают здание от чрезмерного воздействия яркого тропического солнца. Другое поражающее воображение здание - кинетическая "танцующая" архитектура Дэвида Фишера. Он создает проекты небоскребов, которые будут двигаться и вращать своих жителей.

Современная архитектура может не только подстроиться под людей и их потребности, но и позволяет экономить дорогостоящие ресурсы, вырабатывая их самостоятельно. Как сказал Кристофер Баудер, один из сподвижников кинетической архитектуры: «Кинетическая архитектура является следующий шаг к созданию нашего окружения. Архитектура всегда была известна как статическая, твердая и тяжелая. Архитектура в будущем будет физически адаптироваться к нашим потребностям и ожиданиям, поскольку изменение является постоянным процессом нашего времени, нашему окружению необходима способность измениться».

Кинетическая архитектура только начинает свое активное развитие, а это значит, что подходит новая эра в сфере зодчества. 


\section{Литература}

1. Вильям Зук. Кинетическая архитектура. - Reinhold, 1970.

2. Хазанова В. Э. Из истории советской архитектуры 1926-1932 гг. Документы и материалы. Рабочие клубы и дворцы культуры. — М., 1984.

3. Пунин Н. Н. Памятник III интернационала. Проект художника В.Е. Татлина.. Петроград: Издание отд. Изоб. Искусств Н.К.П., 1920. — С.

4. Динамическая красота: кинетическое искусство - 2016. [электронный ресурс] Режим доступа. — URL: http://thewallmagazine.ru/kinetic-art/ (дата обращения 20.01.2017). 